\begin{tabular}{|c|c|c|}
\hline 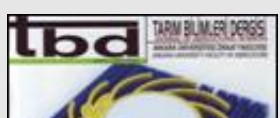 & $\begin{array}{l}\text { Tarım Bilimleri Dergisi } \\
\text { Tar. Bil. Der. }\end{array}$ & Journal of Agricultural Sciences \\
\hline & $\begin{array}{c}\text { Dergi web sayfası: } \\
\text { www.agri.ankara.edu.tr/dergi }\end{array}$ & $\begin{array}{c}\text { Journal homepage: } \\
\text { www.agri.ankara.edu.tr/journal }\end{array}$ \\
\hline
\end{tabular}

\title{
Observation of Weed Species, Frequency and Density in Common Barley (Hordeum vulgare L.) Fields of Diyarbakir, Turkey: A Case Study
}

\author{
Firat PALA ${ }^{\text {a }}$ \\ $\boldsymbol{a}_{\text {Siirt University, Faculty of Agriculture, Department of Plant Protection, Siirt, TURKEY }}$
}

\author{
ARTICLE INFO \\ Research Article \\ Corresponding Author: Firat PALA, E-mail: firatpala @siirt.edu.tr, Tel: +90 (484) 2121111 \\ Received: 22 January 2018, Received in Revised Form: 18 February 2019, Accepted: 09 March 2019
}

AUTHORS ORCID ID

(Firat PALA: 0000-0002-4394-8841)

\begin{abstract}
The weed species in the common barley (Hordeum vulgare L.) fields in the Diyarbakir were observed with this study. For this purpose, 50 quadrats of $1 \mathrm{~m}$ by $1 \mathrm{~m}\left(1 \mathrm{~m}^{-2}\right)$ were randomly placed and examined at each study site. In every set of the quadrat, frequency and density were observed throughout the cropping season of 2015-2016. During the course of field study 72 weed species belonging to 21 families, 13 grasses, 59 broadleaves were recorded. The common families were Asteraceae and Poaceae in the common barley fields. The encounter frequency of weeds was determined by observing $80 \%$ wild mustard (Sinapis arvensis L., 80\%), animated oat (Avena sterilis L., $63 \%$ ), common wild oat
\end{abstract}

(Avena fatua L., 54\%), corn buttercup (Ranunculus arvensis L., 54\%), corn poppy (Papaver rhoeas L., 52\%), creeping thistle (Cirsium arvense (L.) Scop., 51\%), volunteer lentils (Lens culinaris Medik., 51\%). Wild mustard, which had the highest frequency was also the densest weed species $\left(5.18\right.$ plant $\left.\mathrm{m}^{-2}\right)$, and other species such as animated oat (4.33 plant $\left.\mathrm{m}^{-2}\right)$, creeping thistle $\left(1.77\right.$ plant $\left.\mathrm{m}^{-2}\right)$, common wild oat (1.72 plant $\left.\mathrm{m}^{-2}\right)$, corn buttercup $\left(1.47\right.$ plant $\left.\mathrm{m}^{-2}\right)$, cleavers $\left(1.38\right.$ plant $\left.\mathrm{m}^{-2}\right)$, corn poppy $\left(1.22\right.$ plant $\left.\mathrm{m}^{-2}\right)$, volunteer lentils $\left(1.07\right.$ plant $\left.\mathrm{m}^{-2}\right)$ were important species at all the observed fields. It was observed that the great infestation was shown by broadleaf weeds due to the lack of effective weed control in the barley areas.

Keywords: Common barley (Hordeum vulgare L.); Weed species; Abundance; Distribution; Infestation

(C) Ankara Üniversitesi Ziraat Fakültesi

\section{Introduction}

The common barley (Hordeum vulgare L.) is an annual grass and long-day plant belonging to the Poaceae family and grown in the cool climate temperatures of spring and winter (Awika 2011; Koehler \& Wieser 2013). It is a significant grain after common wheat (Triticum aestivum L.), rice (Oryza sativa L.) and corn (Zea mays L.) as global (IGC 2018). The worldwide common barley production has been between 130 and 150 million tons from year to year. Turkey's annual production has been between 7-8 million tons (FAOSTAT 2014). Southeastern Anatolia Region of Turkey, which has $16 \%$ of the production of barley due to animal husbandry and marketing opportunities. The Diyarbakir, which is the grain center of the region, grows $2 \%$ of the country's common barley production (TUIKSTAT 2015). The barley is the principal dryland crop, and general winter planted in the region, both two-rowed (Namely; Sahin-91, Sur-93, Samyeli, Baris and Hevsel) and six-rowed (Namely; Kral-97, Vamik Hoca-98, Akhisar, Kendal and Altikat) varieties are grown (TTSM 2018). The selection of two-rowed or six-rowed barley varieties by farmers depends on the current environment, climate and diversity. Both are used to make animal feeding, malting and food making (Coken \& Akman 2016; AHDB 2018). There are many abiotic and biotic factors such as temperature, light, and soil (nutrients), bugs, fungi, 
bacteria and weeds that can cause yield loss in the common barley crop. The severity of yield loss depends on water capacity of the soil, drought, frost, barley varieties, planting norm and density of diseases, pests, and the weeds (Afentouli \& Eleftherohorinos 1996; Samarah 2005; Jaggard et al 2010; Schumacher et al 2018).

Although the common barley has a suffocating effect on various weeds through crop intervention (Lanning et al 1997), some weeds have the potential to reduce yield (Lyon \& Young 2015). The weeds not only compete with the common barley for nutrients, water and light, but can also make crop harvesting more difficult, increase clamping, and promote insect infestation or mold growth in stored grain (Swanton et al 2015). The common barley crop that is contaminated with the weeds may not be able to reach malt species, and the taste can be reduced when used as animal feed, therefore the weeds reduce crop quality. In the common barley fields, the grass weeds such as common oat (Avena fatua L.), animated oat (Avena sterilis L.), rigid rye-grass (Lolium rigidum L.), and canarygrass (Phalaris brachystachys L.) are the most threatening to the barley production. The broadleaf weeds such as cornflower (Centaurea cyanus L.), knapweed (Centaurea depressa Bieb.), thistle [Cirsium arvense (L.) Scop.], field bindweed (Convolvulus arvensis L.), wild carrot (Daucus carota L.), cleavers (Galium aparine L.), prickly lettuce (Lactuca serriola L.), groundsel (Senecio vulgaris L.), wild mustard (Sinapis arvensis L.), and false carrot [Turgenia latifolia (L.) Hoffm.] are the most threatening species for the barley growth (Turk \& Tawaha 2003; Kordali \& Zengin 2011; Guncan 2014; Tepe 2014; Veisi \& Moeini 2015).

Increased knowledge on how to identify and destruction of the weeds in the common barley produced areas reasonable a significant tactic for the weed control. The prevalence level and development of the abundance and dispersal of the weeds depend on weed control methods. Weed determination researches can supply valued data to growers and scientist on whether weed control is warranted, and if so, what are the favorable weed management strategies (Kumar \& Jha 2017). The aim of this study is to contribute to the academic literature on weeds that have caused problems in the barley cultivated fields. In addition to the barley cultivation, the study raises awareness that weeds can pose a threat to long-term sustainable weed control. Therefore, this research was undertaken to detect the frequency and density of the weeds in the barley fields.

\section{Material and Methods}

\subsection{Plant material and field trial}

The current study deals with weed species found in the Diyarbakir common barley fields. The study was based on surveys of common barley covered area during the cropping seasons of 2015-2016. The sampling areas were selected to represent the area according to the size of the sowing area and the samples were calculated by the sectioned sampling method (Bora \& Karaca 1970). Survey studies were carried out in all of the 17 districts where the common barley is grown in the Diyarbakir province. For these purposes, 180 fields of the common barley were observed across the Diyarbakir located in Southeastern Anatolia Region to find out more about weed species in the 2015-2016 cropping season (Figure 1).

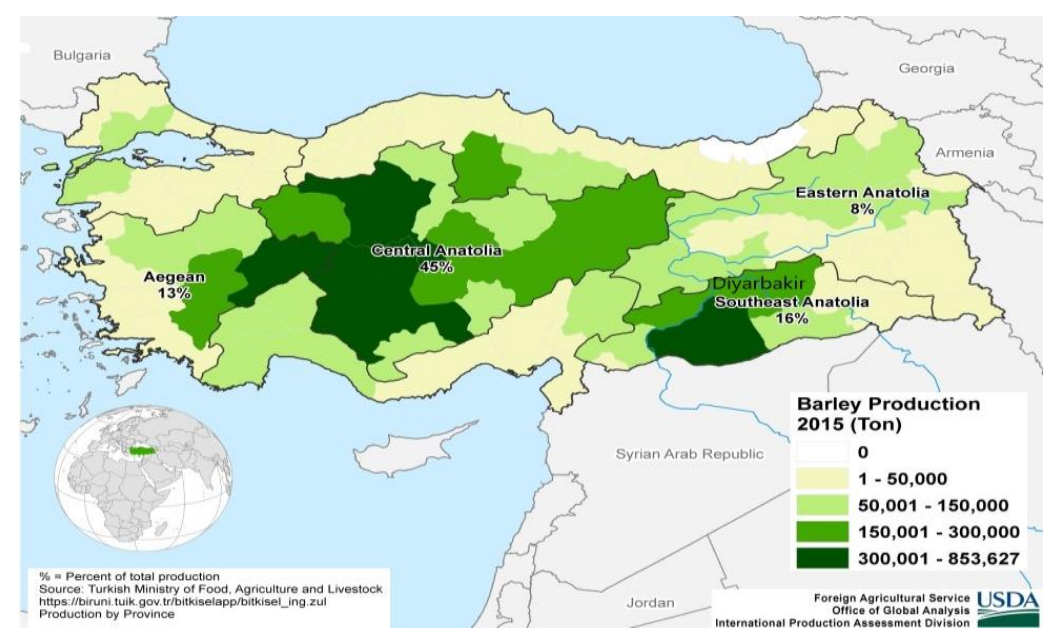

Figure 1- The location of the studied area Diyarbakir province in Turkey

Journal of Agricultural Sciences (Tarım Bilimleri Dergisi) 26 (2020) 164-172 
As a result of this, a proportional distribution was made taking into account the maximum production areas (Table 1).

Table 1- Barley cultivation areas and sampling numbers according to the districts of Diyarbakir province

\begin{tabular}{lrc}
\hline Districts & $\begin{array}{r}\text { Barley fields } \\
(\text { da })^{*}\end{array}$ & $\begin{array}{c}\text { Sample } \\
\text { number }\end{array}$ \\
\hline Baglar & 30.000 & 10 \\
Bismil & 105.885 & 36 \\
Cermik & 22.194 & 7 \\
Cinar & 68.540 & 23 \\
Cüngüs & 4.996 & 2 \\
Dicle & 4.977 & 2 \\
Egil & 17.956 & 6 \\
Ergani & 120.000 & 40 \\
Hani & 17.914 & 6 \\
Hazro & 5.500 & 2 \\
Kayapinar & 9.000 & 3 \\
Kocakoy & 3.500 & 1 \\
Kulp & 39.227 & 13 \\
Lice & 649 & 1 \\
Silvan & 10.000 & 3 \\
Sur & 70.000 & 24 \\
Yenisehir & 2.971 & 1 \\
\hline Total & 533.309 &
\end{tabular}

The field studies were carried out during the peak weed growth season, which is from March to May when weeds could be easily identified. Field surveys were performed twice a week to each site to collect weed species. Care has been taken to ensure that there was a minimum distance of $3 \mathrm{~km}$ between each field in the fields where the sample was taken from. During this research, interviews were carried out with producer and agriculturists from each field concerning weed species which are characteristic of a particular season of the year and important notes on germination, 2-6 leaves, flowering and fruiting seasons of weeds. The counts have been started within at least $10 \mathrm{~m}$ of the fields to remove the edge effect. Quadrats $1 \mathrm{~m}$ by $1 \mathrm{~m}\left(1 \mathrm{~m}^{2}\right)$ were randomly laid down in the agricultural fields to quantify various weed species, and they were used 4 times for a decare chosen to represent the field in the fields studied (Odum 1971).

\subsection{Computation and data analysis}

The broadleaf weeds were evaluated as whole plants and the grasses were evaluated as stalks and were reported survey forms. The vegetation structure and composition in the agricultural areas have been compared with the plant frequency and density, which is the simplest and most popular measurement methods for measuring abundance and distribution of weed species (Nkoa et al 2015). Different phytosociological parameters such as plant frequency $(\%)$ and density (plant $\mathrm{m}^{-2}$ ), were calculated by using the following equations (Guncan 2014):

$\%$ Frequency $=($ Number of sampling units in which the species occurs $(N)) /($ Total number of sampling units employed for the study $(Q))^{*} 100$

$F=(N / Q) * 100$

Where; $F$, frequency; $N$, number of quadrats in which the species is present; $Q$, total number of quadrats studied.

Density $=($ Total number of individuals of the species in all the sampling unit $(S)) /($ Total number of sampling units studied $(Q))$ 
$D=(S / Q)$

Where; $D$, density; $S$, total number of individuals; $Q$, total number of quadrats studied.

The weed species that could not be diagnosed in the field were appropriately collected, pressed, dried, preserved and identified according to Davis (1965-1989). The same grading method was used to score the predominant weed species. The weeds were recorded in the field when the density of weed species was less than $20 \%$ per square meter, from 20 to $40 \%$ in medium and when the density was more than $40 \%$.

\section{Results and Discussion}

As a result of observations made in the common barley fields of the Diyarbakir, there were 72 weed species belonging to 21 families; including 13 monocotyledons, and 59 dicotyledons. The overall results of common barley weeds were presented in Table 2. The main biological groups were identified: monocots and dicots, annuals, biennials, and perennials, including rhizome plants. A. fatua, A. sterilis, C. arvense, G. aparine, L. culinaris, $P$. rhoeas, $P$. bractystachys, $R$. arvensis, $S$. arvensis, $T$. latifolia were determined as highly spread in the common barley field. According to the results of the survey, it can be concluded that the most common weed families in the common barley fields in the region were 13 species of the Asteraceae and Poaceae. In addition, other families such as Brassicaceae, Fabaceae, Caryophyllaceae, Apiaceae, Ranunculaceae, Geraniaceae, Papaveraceae etc. was recorded, but at low levels with less than 10 weed species. The weed families identified in the study (Figure 2).

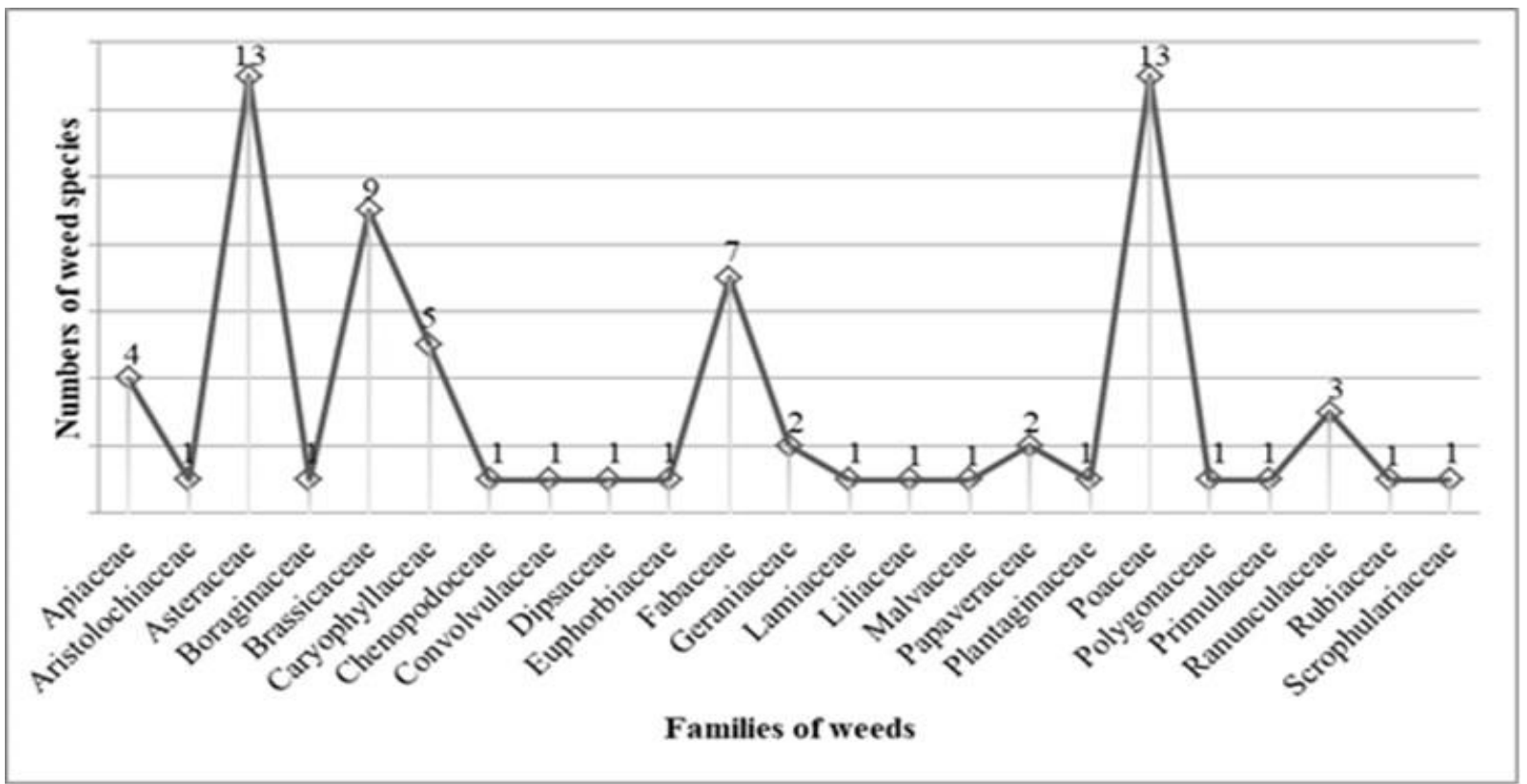

Figure 2- Families of weed species in barley cultivated areas of Diyarbakir province and the number of weed species owned by these families

The results of the surveys conducted in the Diyarbakir common barley fields showed that the frequency of the occurrence of more than $50 \%$ was Sinapis arvensis L. (80\%), Avena sterilis L. (63\%), Avena fatua L. (54\%), Ranunculus arvensis L. (54\%), Papaver rhoeas L. (52\%), Cirsium arvense (L.) Scop. (51\%), Lens culinaris Medik (51\%). When evaluated according to the density of weeds; Sinapis arvensis L. (5.18 plant $\left.\mathrm{m}^{-2}\right)$, Avena sterilis L. (4.33 plant $\left.\mathrm{m}^{-2}\right)$, Cirsium arvense (L.) Scop. (1.77 plant $\left.\mathrm{m}^{-2}\right)$, Avena fatua L. (1.72 plant $\left.\mathrm{m}^{-2}\right)$,

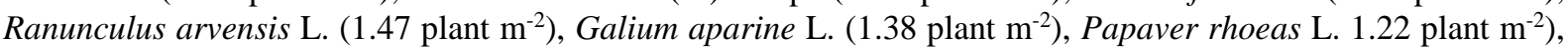
Lens culinaris Medik (1.07 plant $\mathrm{m}^{-2}$ ) species were found to be more than one in square meters (Table 2). It was seen that the densest and frequent species were S. arvensis and A. sterilis. However, there were some parallels in the frequency and density of weeds. For example, both the frequency and intensity of Ranunculus arvensis had been detected in the unit area. 
Table 2- Frequency and density of weeds detected in barley fields of Diyarbakir

\begin{tabular}{|c|c|c|c|c|}
\hline Scientific names of weeds & Common names of weeds & Family & $F^{*}$ & $D^{* *}$ \\
\hline Adonis aestivalis $\mathrm{L}$. & Summer pheasant's eye & Ranunculaceae & 5 & 0.27 \\
\hline Agrostemma githago L. & Common corncockle & Caryophyllaceae & 5 & 0.10 \\
\hline Allium sp. & Onion & Liliaceae & 2 & 0.05 \\
\hline Alopecurus myosuroides Huds. & Meadow foxtail & Poaceae & 15 & 0.46 \\
\hline Anagallis arvensis L. & Scarlet pimpernel & Primulaceae & 7 & 0.15 \\
\hline Anchusa azurea Miller. & Italian bugloss & Boraginaceae & 2 & 0.04 \\
\hline Anthemis arvensis L. & Mayweed & Asteraceae & 20 & 0.35 \\
\hline Aristolochia maurorum L. & Birthwort & Aristolochiaceae & 8 & 0.15 \\
\hline Avena fatua $\mathrm{L}$. & Common wild oat & Poaceae & 54 & 1.72 \\
\hline Avena sterilis $\mathrm{L}$. & Animated oat & Poaceae & 63 & 4.33 \\
\hline Bifora radians $\mathrm{Bieb.}$ & Wild bishop & Apiaceae & 25 & 0.45 \\
\hline Boreava orientalis Jaub and Spach. & Yellow weed & Brassicaceae & 14 & 0.35 \\
\hline Bromus tectorum $\mathrm{L}$. & Cheatgrass & Poaceae & 25 & 0.68 \\
\hline Capsella bursa-pastoris (L.) Medik. & Shepherd's purse & Brassicaceae & 21 & 0.67 \\
\hline Cardaria draba (L.) Desv. & Whitetop hoary cress & Brassicaceae & 9 & 0.16 \\
\hline Carduus pycnocephalus L. & Italian thistle & Asteraceae & 3 & 0.09 \\
\hline Caucalis platycarpos $\mathrm{L}$. & Bur-parsley & Apiaceae & 1 & 0.01 \\
\hline Centaurea depressa Bieb. & Cornflower & Asteraceae & 16 & 0.46 \\
\hline Centaurea solstitialis L. & Yellow star-thistle & Asteraceae & 13 & 0.34 \\
\hline Cephalaria syriaca (L.) Schrad. & Syrian cephalaria & Dipsaceae & 6 & 0.15 \\
\hline Cerastium dichotomum $\mathrm{L}$. & Mouse-ear chickweed & Caryophyllaceae & 5 & 0.09 \\
\hline Chondrilla juncea $\mathrm{L}$. & Rush skeletonweed & Asteraceae & 14 & 0.35 \\
\hline Cichorium intybus L. & Common chicory & Asteraceae & 14 & 0.17 \\
\hline Cirsium arvense (L.) Scop. & Canada thistle & Asteraceae & 51 & 1.77 \\
\hline Consolida orientalis (Gay) Schrid. & Larkspur & Ranunculaceae & 6 & 0.13 \\
\hline Convolvulus arvensis L. & Field bindweed & Convolvulaceae & 25 & 0.89 \\
\hline Daucus carota $\mathrm{L}$. & Wild carrot & Apiaceae & 21 & 0.56 \\
\hline Descurainia sophia (L.) Webb & Flixweed & Brassicaceae & 2 & 0.03 \\
\hline Erodium hoefftianum C.A.Mey & Redstem filaree & Geraniaceae & 9 & 0.19 \\
\hline Euphorbia helioscopia L. & Sun spurge & Euphorbiaceae & 3 & 0.07 \\
\hline Fumaria officinalis L. & Common fumitory & Papaveraceae & 22 & 0.66 \\
\hline Galium aparine $\mathrm{L}$. & Cleavers & Rubiaceae & 45 & 1.38 \\
\hline Geranium dissectum $\mathrm{L}$. & Cut-leaved crane's-bill & Geraniaceae & 23 & 0.92 \\
\hline Hordeum murinum L. & Mouse barley & Poaceae & 9 & 0.03 \\
\hline Lactuca serriola L. & Prickly lettuce & Asteraceae & 22 & 0.65 \\
\hline Lamium amplexicaule $\mathrm{L}$. & Henbit dead-nettle & Lamiaceae & 12 & 0.25 \\
\hline Lathyrus sp. & Chickling pea & Fabaceae & 4 & 0.08 \\
\hline Lens culinaris Medik & Volunteer lentil & Fabaceae & 51 & 1.07 \\
\hline Lolium temulentum L. Lam. & Darnel ryegrass & Poaceae & 11 & 0.18 \\
\hline Lolium rigidum $\mathrm{L}$. & Wimmera ryegrass & Poaceae & 27 & 0.38 \\
\hline
\end{tabular}


Table 2 (Continue)- Frequency and density of weeds detected in barley fields of Diyarbakir

\begin{tabular}{|c|c|c|c|c|}
\hline Scientific names of weeds & Common names of weeds & Family & $F^{*}$ & $D^{* *}$ \\
\hline Malva neglecta Wallr. & Dwarf mallow & Malvaceae & 6 & 0.12 \\
\hline Matricaria chamomilla L. & Chamomile & Asteraceae & 7 & 0.17 \\
\hline Medicago sativa $\mathrm{L}$. & Alfalfa & Fabaceae & 5 & 0.25 \\
\hline Myagrum perfoliatum L. & Musk weed & Brassicaceae & 8 & 0.11 \\
\hline Neslia paniculata (L.) Devs. & Ball mustard & Brassicaceae & 8 & 0.24 \\
\hline Papaver rhoeas L. & Common poppy & Papaveraceae & 52 & 1.22 \\
\hline Phalaris brachystachys Link. & Short-spiked canarygrass & Poaceae & 42 & 0.48 \\
\hline Phalaris canariensis L. & Canarygrass & Poaceae & 25 & 0.29 \\
\hline Phragmites communis Trin. & Common reed & Poaceae & 5 & 0.20 \\
\hline Pisum sativum $\mathrm{L}$. & Garden pea & Fabaceae & 8 & 0.17 \\
\hline Plantago lanceolata L. & Ribwort plantain & Plantaginaceae & 3 & 0.06 \\
\hline Poa annua $\mathrm{L}$. & Bluegrass & Poaceae & 2 & 0.01 \\
\hline Poa trivialis L. & Rough bluegrass & Poaceae & 26 & 0.42 \\
\hline Ranunculus arvensis L. & Corn buttercup & Ranunculaceae & 54 & 1.47 \\
\hline Rumex crispus L. & Curly dock & Polygonaceae & 1 & 0.02 \\
\hline Salsola kali L. & Russian thistle & Chenopodoceae & 6 & 0.12 \\
\hline Secale cereale $\mathrm{L}$. & Cereal rye & Poaceae & 6 & 0.10 \\
\hline Senecio vulgaris L. & Groundsel & Asteraceae & 5 & 0.08 \\
\hline Silene conoidea $\mathrm{L}$. & Large sand catchfly & Caryophyllaceae & 6 & 0.14 \\
\hline Silene vulgaris (Moench) Garcke. & Bladder campion & Caryophyllaceae & 4 & 0.18 \\
\hline Silybum marianum (L.) Gaertner & Milk thistle & Asteraceae & 17 & 0.35 \\
\hline Sinapis arvensis L. & Wild mustard & Brassicaceae & 80 & 5.18 \\
\hline Sisymbrium officinale (L.) Scop. & Hedge mustard & Brassicaceae & 9 & 0.24 \\
\hline Sonchus asper (L.) Hill. & Spiny sowthistle & Asteraceae & 3 & 0.06 \\
\hline Sonchus oleraceus L. & Common sowthistle & Asteraceae & 4 & 0.35 \\
\hline Thlaspi arvense L. & Field pennycress & Brassicaceae & 15 & 0.89 \\
\hline Trifolium $\mathrm{sp}$. & Clover & Fabaceae & 4 & 0.13 \\
\hline Turgenia latifolia (L.) Hoffm. & Broadleaf false carrot & Apiaceae & 41 & 0.96 \\
\hline Vaccaria pyramidata Medik & Cowherb & Caryophyllaceae & 17 & 0.52 \\
\hline Veronica hederifolia L. & Ivy-leaved speedwell & Scrophulariaceae & 21 & 0.30 \\
\hline Vicia faba L. & Broad bean & Fabaceae & 1 & 0.02 \\
\hline Vicia sativa $\mathrm{L}$. & Common vetch & Fabaceae & 8 & 0.44 \\
\hline
\end{tabular}

$* \mathrm{~F}$, frequency $(\%) ; * * \mathrm{D}$, density $\left(\right.$ plant $\left.\mathrm{m}^{-2}\right)$

As a result of exploratory realized to detect the frequency and density of weed species seen in the common barley fields of the Diyarbakir, the numbers of species of Asteraceae and Poaceae were found to be higher in a number of species. It is a natural result that most of the weed species have emerged from these two families because the plant families are two of the families with the highest species in our city cereal fields (Pala \& Mennan 2017). Previous surveys had shown that these two families are among the most species-bearing families (Kordali \& Zengin 2011). 
As a result of the surveys carried out, it was observed that winter weed species (S. arvensis, A. sterilis, C. arvense, $R$. arvensis, G. aparine) were problematic. It is anticipated that these species, which have been well adapted to these ecological conditions because of the cold and rainy winters and hot and dry summers in the Diyarbakir, are expected to be a problem in grain fields (Zel 1974; Uludağ 1997; Sizer \& Tepe 2016; Pala \& Mennan 2017). This work is very important because it contains data that will form the basis of weed control work to be done in the common barley.

Climate, agricultural activities, and especially applied the weed control methods can change the weed composition in agricultural areas. Ergani, Bismil, Sur and Cinar districts of the Diyarbakir province were found to be heavily weeded in monoculture farming areas where dry farming was done. Crop rotation decreased weed species (Pala et al 2018), but it wasn't enough alone. Hence there was no obvious effect on the weed flora these districts.

Identification of weed distribution can be a significant point in the weed control in the common barley production. Monitoring weeds in the studied areas will help to define the implementation of appropriate management preventions (Moeini et al 2008). Veisi \& Moeini (2015) found that C. arvense and C. depressa species, also Avena, Galium, and Vicia, a genus which is the prominent weeds in Kermanshah common barley areas, observed in the Diyarbakir too, this indicates that these weeds can be a trouble in different ecosystems. The very limited study had been done on weeds which are a problem in the common barley fields, both in Turkey and the world. Therefore, there are limited studies to compare weed species in Diyarbakir barley fields with weeds in other barley cultivation areas. The weed species found by Kordali \& Zengin (2011) in the common barley fields of Bayburt differ significantly in terms of species and density compared to the weeds we have identified in our study. This explains the frequency and density of the weed species, density, and coverage areas vary in different regions and years. Various factors such as early planting, densely sown and appropriately fertilized can apply to enhance crop yield in common barley in small agricultural systems of semi-arid regions and reduce weed populations (Elwis \& Young 2000; Poggio 2005). Santin-Montanya et al (2013) reported that the application of new farming techniques led to constant changes in the weed population, while some strains of some weeds lost some of the previously no problematic species. On the other hand, Schumacher et al (2018) note that the loss of weed biodiversity in agricultural fields is a global issue that should be avoided to protect the supported ecosystem services and food networks. The weed flora of the product varies from field to field depending on the environment terms, irrigation systems, fertilization, soil structure and weed management (Anderson \& Beck 2017). Inadequate weed management in the Diyarbakir common barley fields and incomplete and faulty applications are increasing the weed problem in these areas. It was observed that chemicals were used to control Avena spp. and Sinapis arvensis, but these weeds could be partially controlled. The results showed that preventive and cultural methods such as certified seed use, development of tolerant variety, deep tillage with the pre-sowing disc, frequent sowing, late sowing should be developed because the current weed control methods are not sufficient. On the other hand, attention should be paid to the avoidance of early and late applications in the fertilization of common barley with the herbicide, the spraying of a well-calibrated sprayer in the appropriate climatic and soil conditions during the 2-6 leaf period of the weeds. In recent years, due to increased resistance to herbicides in the weeds of cereals in the Diyarbakir (Sizer \& Tepe 2016), the rotation of the herbicide is an important consideration to be taken to reduce the weed populations. Awareness activities of the common barley producers need to be done on the weeds.

\section{Conclusions}

The Diyarbakir is one of the common barley gene and production center in Turkey. Several researchers have tried to explore of the weeds, but the studies on species diversity of weeds in the common barley are still unscreened. Hence, in the present study attempts were made to screen out the structure of weed communities associated with the common barley crop. This study provides preliminary data of the different categories of weeds in the common barley crop fields. According to the results of the survey, it can be concluded that the common barley plants in the region are affected by a series of the weeds. It was found that the broadleaf weeds were significant, especially Sinapis arvensis and Ranunculus arvensis were dense in the common barley which is known to have highly competitive with weeds. Consequently, the weeds were a serious concern in the common barley fields, in particular, the winter weeds were a serious problem in the common barley fields, hence it ought to seek new solutions for controls. The study is helpful to farmers, agronomists, and researchers related to this 
field for identification of weeds and to understand the distribution and growth patterns of weeds associated with the common barley fields. During the study, it became obvious that farmers should be trained in suitable common barley crop management practices and need to make better access to advanced weed management practices. New varieties that are tolerant to the climatic factors and herbicides, resistant to diseases and insects and that have strong weed competition, meet production and consumer's needs should continue to grow. Weed identification and control should be taken critically. It is obvious that the frequency and density of the weed species in the common barley fields will decrease losses of the common barley crop yield. Proper control of the weeds will increase the yield of common barley cultivation and total grain production. In this context, field observations to make necessary and collect information about the frequency and density of the weeds, to evaluate the economic losses caused by the weeds and to improve the new weed management tactics for the common barley production. In addition, it is concluded that weed needs to be investigated for the weed bank dynamics to a better estimate of the weed populations.

\section{References}

Afentouli C G \& Eleftherohorinos I G (1996). Littleseed canarygrass (Phalaris minor) and short spiked canarygrass (Phalaris brachystachys) interference in wheat and barley. Weed Science 44: 560-565

AHDB (2018). AHDB Cereals \& Oilseeds. Agriculture and Horticulture Development Board, Barley growth guide, Retrieved on December 22, 2018 from https://cereals.ahdb.org.uk/media/186381/g67-barley-growth-guide.pdf

Anderson R L \& Beck D L (2017). Characterizing weed communities among various rotations in central South Dakota. Weed Technology 21: 76-79

Awika J M (2011). Major cereal grains production and use around the world. ACS Symposium Series, 1089: 1-13

Bora T \& Karaca I (1970). Measurement of Disease and Loss in Cultures. Ege University Faculty of Agriculture Supplementary Textbook. Publication No: 167, pp. 43, Izmir

Coken I \& Akman Z (2016). Determination of yield and quality characteristics of barley cultivars in Isparta ecological conditions. Süleyman Demirel University Journal of Natural and Applied Sciences 20(1): 91-97

Davis P H (1965-1989). Flora of Turkey and East Aegean Islands. Edinburgh University Press., Vol. 1-11, Edinburgh

Elwis G S \& Young D L (2000). The economic and environmental revolution in Semi-arid cropping in North America. Annals of Arid Zone 39(3): 347-361

FAOSTAT (2014). Statistical data of FAOSTAT. Retrieved on November 19, 2014 from http://www.fao.org/faostat/en/\#home

Guncan A (2014). Weed Management (Yabancı Ot Mücadelesi). Selcuk University Agriculture Faculty Publication, Konya, pp. 4-39

IGC (2018). International Grain Council. Retrieved on September 14, 2018 from https://www.igc.int/en/default.aspx

Jaggard K W, Qi A \& Ober E S (2010). Possible changes to arable crop yields by 2050. Philosophical Transactions of the Royal Society B, Biological Sciences 365: 2835-2851

Koehler P \& Wieser H (2013). Chemistry of Cereal Grains. In: Gobbetti M., Gänzle M. (Eds) Handbook on Sourdough Biotechnology. Springer, Boston, MA pp. 11-45

Kordali S \& Zengin H (2011). Studies on weeds and their density, frequency, and association in barley fields in Bayburt Provinces. Journal of Agriculture Faculty of Atatürk University 42(2): 117-131

Kumar V \& Jha P (2017). Influence of nitrogen rate, seeding rate, and weed removal timing on weed interference in barley and effect of nitrogen on weed response to herbicides. Weed Science 65(1): 189-201

Lanning S P, Talbert L E, Martin J M, Blake T K \& Bruckner P L (1997). The genotype of wheat and barley affects light penetration and wild oat growth. Agronomy Journal 89: 100-103

Lyon D J \& Young F L (2015). Integration of weed management and tillage practices in spring barley production. Weed Technology 29(3): 367-373

Journal of Agricultural Sciences (Tarım Bilimleri Dergisi) 26 (2020) 164-172 
Moeini M M, Baghestani M A \& Rahimian H (2008). Introducing an abundance index for assessing weed flora in survey studies. Weed Biology and Management 8: 172-180

Odum E P (1971). Fundamentals of Ecology, $3^{\text {rd }}$ Edition, W.B. Saunders Company, Philadelphia-London-Toronto

Nkoa R, Owen M D K \& Swanton C J (2015). Weed abundance, distribution, diversity, and community analyses. Weed Science 63(1): 64-90

Pala F \& Mennan H (2017). Determination of weed species in wheat fields of Diyarbakir province. Plant Protection Bulletin 57(4): 447-461

Pala F, Mennan H \& Demir A (2018). Determination of the weed species, frequency, and density in lentil fields in Diyarbakir Province. Turkish Journal of Weed Science 21(1): 33-42

Poggio S L (2005). Structure of the weed communities occurring in monocultures and intercrops of field pea and barley. Agriculture, Ecosystems and Environment 109: 48-58

Samarah N H (2005). Effects of drought stress on growth and yield of barley. Agronomy for Sustainable Development 25: 145-149

Santin-Montanya I, Zambrana-Quesada E \& Tenorio-Pasamón J L (2013). Weed Management in Cereals in Semi-Arid Environments: A Review. Andrew J. Price and Jessica A. Kelton, IntechOpen, Chapter 6, pp. 133-152

Schumacher M, Ohnmacht S, Rosenstein R \& Gerhards R (2018). How management factors influence weed communities of cereals, their diversity and endangered weed s0pecies in Central Europe. Agriculture 8(11): 172-185

Sizer V \& Tepe I (2016). Determination of susceptibility of winter wild oat (Avena sterilis L.) biotypes against clodinafoppropargyl and metsosulfuron- methyl + iodosulfuron - methyl - sodium herbicides prevalent in wheat fields of Diyarbakir, Turkey. Turkish Journal of Weed Science 19(2): 10-19

Swanton C J, Nkoa R \& Blackshaw R E (2015). Experimental methods for crop-weed competition studies. Weed Science 63(1): $2-11$

Tepe I (2014). Weed Management (Yabancı Otlarla Mucadele). Sidas Media Agriculture Publication: 31, Izmir, pp. 13-25

TTSM (2018). Variety Registration and Seed Certification Center. Southeastern Anatolia Region barley registration report. Retrieved on March 12, 2018 from https://www.tarimorman.gov.tr/BUGEM/TTSM/Sayfalar/EN/AnaSayfa.aspx

TUIKSTAT (2015). Statistical data of TUIKSTAT. Retrieved on December 17, 2015 from https://biruni.tuik.gov.tr/ bitkiselapp/bitkisel.zul

Turk M A \& Tawaha A M (2003). Weed control in cereals in Jordan. Crop Protection 22: 239-246

Uludağ A (1997). Weed infestation level changes in cereals in Diyarbakir, Turkey. 10 ${ }^{\text {th }}$ EWRS Symposium, 22-26 June, Poznan, Poland, Proceedings: pp. 22

Veisi M \& Moeini M M (2015). Determination of population indices and weed distribution map in barley fields of Kermanshah Province, Iran. Journal of Biodiversity and Environmental Sciences 7(1): 446-458

Zel N (1974). Surveys on weed varieties present in cereal fields in Eastern and Southeastern Anatolia Regions. Agricultural Management Research Yearbook, pp. 8-80 